\title{
The Effect of Brain Based Learning Strategies and Project Based Learning on Mathematics Learning Outcomes in Students of the Kinesthetic Learning Style Group
}

\author{
La Ode Ahmad Jazuli, Etin Solihatin, Zulfiati Syahrial
}

\begin{abstract}
Brain-based learning is a concept of strategy to create learning-oriented efforts to empower students' brain potential. Project-Based Learning is a learning strategy that utilizes projects or activities as a center of learning. The purpose of this study was to examine the effect of brain-based learning and project-based learning strategies on student mathematics learning outcomes, especially kinesthetic learning style groups. The quasi-experimental research method is post-test only design, retrieval of learning outcomes data with tests and learning styles using questionnaires and data analysis using ANOVA with t-Dunnet advanced tests. This study found that the mathematics learning outcomes of students who were taught using the Project-Based Learning strategy were higher than those taught by the Brain-Based Learning (BBL) learning strategy especially for students in kinesthetic learning styles. The suitability of investigative activities creates products in project-based learning with the characterization of students' kinesthetic learning styles which are characterized by always touching certain information objects can strengthen the memory of meaningful information and knowledge so as to improve the quality of learning outcomes.
\end{abstract}

Keywords: Project-Based Learning / Brain-Based Learning, Kinesthetic Learning Style.

\section{INTRODUCTION}

Education is one form of embodiment of human culture that is dynamic and full of development. There is no alternative to fulfillment in terms of relevance, the demand for achievement of learning outcomes has not been encouraging for all education stakeholders(Gullick et al., 2018) ; (Viberg, Hatakka, Bälter, \& Mavroudi, 2018) especially those related to the demands of output profiles of education graduates and learning outcomes that require future Indonesian human resource qualifications (Glewwe \& Muralidharan, 2016) that include knowledge, attitudes and skills which has adaptability to the latest dynamics of life competition. Mathematics is one of the subjects that requires a high level of understanding to achieve maximum results. The learning methods and processes ( $\mathrm{Yu}$, Zheng, \& Wang, 2019);(Abdi, Rahmati, \& Ebadzadeh, 2019); (Li, Zhang, Sun, $\&$ Gao, 2019). That have been taking place using the existing curriculum have made the results achieved are not in

Revised Manuscript Received on September 22, 2019 Universitas Negeri Jakarta, Indonesia.

Etin Solihatin, educational technology study program, Universitas Negeri Jakarta, Jakarta, Indonesia.

Zulfiati Syahrial, educational technology study program, Universitas Negeri Jakarta, Jakarta, Indonesia.
La Ode Ahmad Jazuli, Education Technology study program,

accordance with the expectations of all parties, both parents, students and Mathematics education majors. Unfinished from choosing the right learning strategy (Ching-Ter, Hajiyev, \& Su, 2017);(Balan, Yuen, \& Mehrtash, 2019); (Choi, Lee, \& Kim, 2019), the evaluation aspect still tends to measure the ability and learning achievement of students only, which is still a problem. The introduction of learning (Moyer-Packenham et al., 2019) styles is very important for lecturers by knowing the learning styles of each student so the lecturer can apply the appropriate techniques and strategies both in learning and in self-development. During the three-year, the low learning outcomes shown by the absorption of material recognized from the average percentage of the achievement of student courses for the last three years are as follows:

Table 1. Data Analysis of Mathematics Subject Value Percentage

\begin{tabular}{|c|c|c|c|c|c|}
\hline \multirow{2}{*}{$\begin{array}{c}\text { ACADEMIC } \\
\text { YEARS }\end{array}$} & \multicolumn{5}{|c|}{$\sum$ GRADE (\%) } \\
\cline { 2 - 6 } & A & B & C & D & E \\
\hline $2014 / 2015$ & 1.3 & 35.5 & 48.39 & 12.26 & 2.58 \\
\hline $2015 / 2016$ & 4.09 & 45.08 & 48.36 & 0 & 2.46 \\
\hline $2016 / 2017$ & 0 & 15.53 & 37.86 & 39.8 & 6.79 \\
\hline RATA & 1.79 & 32.03 & 44.87 & 17.35 & 3.94 \\
\hline
\end{tabular}

The above table shows the value of the Basic Mathematics subject which describes real problems as basic courses as well as the prerequisites in the curriculum structure of the mathematics education undergraduate program at UHO, because in this course the basic concepts of building mathematical theories are Logic and Set. Furthermore, the results of the interviews with lecturers of the subject were learning difficulties experienced by students basically because they did not fully understand what they were learning. The lack of students' understanding of what they learned was partly due to mathematical objects being abstract concepts, suitability of applied learning strategies and the introduction of characteristics as new students.

The renewal of learning mathematics in essence aims to dismiss the notion for most people that mathematics is a difficult subject matter. Constructive and cognitive theory result various concepts, models and learning strategies. One of it is Brain Based Learning (BBL) strategy (Kapadia, 2014) motivated by the general belief that learning can be accelerated and improved if educators base how and what 
they teach on learning science, not on past practices of conventional education or assumptions about the learning process Brain-Based Learning (BBL) Strategy as a student centered learning method by utilizing (McCabe, 2018) all brain functions and recognizing that all students can learn in different ways as a demand for learning that uses problems as a first step in collecting and integrating new knowledge based on student experience in activities. This is in accordance with the concept of Project Based Learning (PjBL). PjBL is designed to be used on complex problems that students need to investigate and understand with an inquiry process starting from raising a guided question and guiding students in a collaborative project by integrating various subjects (material) in the curriculum. This actually states that improving education in Indonesia requires a planned breakthrough from all stakeholders by taking part in solving problems from aspects that are directly related or not to the issue of education. Looking at the reality as described and the urgency of implementing the learning strategy, the purpose of this study is to examine the effect of BBL and PjBL learning strategies on the mathematics learning outcomes of students in the kinesthetic learning style group.

The results of the same study previously reported that Brain Based Learning (BBL) on student motivation and attitudes (Akyürek, 2013); Brain Based Learning (BBL) with students' mathematical inability (Faramarzi, Samadi, Yarmohammadian, \& Dezhara, 2014); (Gözüyeşill, 2014). Brain Based Learning (BBL) and the ability to think creatively (Widiana, Bayu, \& Jayanta, 2017)(16); Brain Based Learning and scholastic abilities (Ningsih, 2017); Brain Based Learning, motivation, mathematical achievement, creative and cognitive style (Widiana et al., 2017); BBL methods and physics learning achievements (Saleh \& Subramaniam, 2018).

Project Based Learning $(\mathrm{PjBL})$ and the results of reading, science, creative ability, and metacognition (Cervantes, 2013);(Ergül \& Kargın, 2014); (Izzati, 2014); Project Based Learning (PjBL) and science teaching self-efficacy (Bilgin, Karakuyu, \& Ay, 2015); Project based and problem solving motivation (Chiang \& Lee, 2015); production oriented approach to teaching English, (Wen, 2018); project-based organizations enhance innovative capacity by utilizing gender diversity for learning outcomes (Baker, Ali, \& French, 2019);

The contribution of cognitive style to the effectiveness of learning (Hamdani, 2015); learning styles and science learning outcomes(Evrim, URAL\& Orhan, ERCAN \& Mehmet Akif, 2015); learning styles and design courses (Valley, 2012); individual differences (An \& Carr, 2017); nursing student learning based on learning styles Kolb (Fatemeh Vizeshfar \& Camellia Torabizadeh, 2018)

Based on the focus of previous research described above, this study is unique and novel, because this experimental study directly compared the effects of brain-based learning (BBL) and project-based learning strategies (PjBL) on student learning outcomes that have kinesthetic learning styles in Basic Mathematics courses in mathematics education department

\section{LITERATURE REVIEW}

Principles in behaviorism learning theory include (Shuell, 2001); (Sedrakyan, Malmberg, Verbert, Järvelä, \& Kirschner, 2018) The Role of Consequences, Reinforcers, Immediacy of Consequences, Shaping (extending gradual reinforcement does not wait until completion (Ou, Chang, \& Chakraborty, 2019), Extincion (extinction of previous behavior), Schedule of reinforcement (this term refers to the frequency of amplifiers given, the amount of time elapsed between opportunities for reinforcement, and predictability of reinforcement, maintenance (maintenance with careful systemic reinforcement) and the Role of antecedents. Next, Cognitive learning theory is based on seven basic principles:(Morgan, Fogel, Nair, \& Patel, 2019) Development and learners depend on the experience of students (Waddington, 2019); (Usher, Ford, Li, \& Weidner, 2019), People want their experiences to make sense. People construct knowledge to understand their experiences, Knowledge depends on prior knowledge and experience and the use of facilitating languages knowledge development. Learning requires practice and feedback(Wang, Gong, Xu, \& $\mathrm{Hu}, 2019$ ), and increases when learning experiences are associated with the real world (Hong et al., 2019) .

\section{Methodology / MATERIALS}

In this study, it used a quasi exsperiment research method (Balbaşi, 2013). The research process consists of 3 (three) stages, namely: Preparation Phase, the preparation of Semester Learning Plans (RPS), Teaching Materials, Instruments, determining treatment classes, preparing colored pencils and cartoon paper etc. in accordance with the applicable curriculum; 2. The Implementation Phase is identification of trends in student learning styles, giving treatment with Brain Based Learning (BBL) strategies and Project Based Learning $(\mathrm{PjBL})$ and learning outcomes tests in both groups of research subjects with the same day, hour, and time allocation; 3. The Final Phase is processing and analyzing data and preparing reports. In particular, the schematic implementation stage is described below.

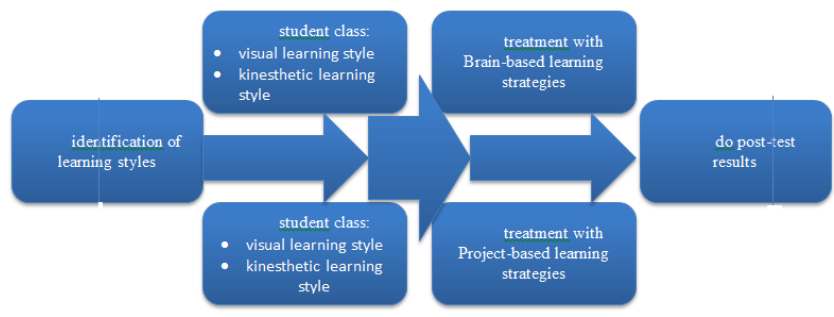

Figure 1. Research Implementation Phase

Student learning outcomes data were collected using valid and reliable test instruments in the form of descriptions totaling 9 items compiled based on Bloom's taxonomy as a result of improvements from Anderson's team on cognitive domain structure used to measure the extent to which students mastered learning the material. While kinesthetic learning style data was collected using 10 valid and reliable questionnaire items in the form of a Likert scale to distinguish trends from Kinesthetic learning styles. Two classes of students were taught BBL and PjBL strategies. Each class was determined by 15 students randomly from the population of 
the kinesthetic learning style group. During the treatment implementation process, internal and external validity controls are carried out to produce a valid research report.

Furthermore, student learning outcomes data were analyzed descriptively and inferentially. Inferential analysis uses the ANOVA technique procedure at a significant level $\alpha$ $=0.05$ after fulfilling the prerequisite analysis test, namely the normality test with liliefors and homogeneity with the bartlet test.

\section{RESULTS AND FINDINGS}

In facing every challenge well in the fourth generation industrial revolution, everyone needs high-level thinking skills with good reasoning, the ability to think creatively, be innovative and think critically.

Descriptive statistical analysis of student learning outcomes taught with Brain Based Learning (BBL) and Project Based Learning (PjBL) in the kinesthetic learning style group are summarized in the following table:

Table 2: Descriptive Analysis of learning outcomes data

\begin{tabular}{|l|r|r|}
\hline & $\mathbf{A}_{\mathbf{1}} \mathbf{B}_{\mathbf{2}}$ & \multicolumn{1}{|c|}{$\mathbf{A}_{\mathbf{2}} \mathbf{B}_{\mathbf{2}}$} \\
\hline $\mathrm{N} \quad$ Valid & 15 & 15 \\
Mean & 15 & 15 \\
Median & 84.466 & 87.0667 \\
Mode & 84.000 & 86.0000 \\
Std. Deviation & 81.00 & 82.00 \\
Minimum & 4.3238 & 5.17503 \\
Maximum & 79.00 & 79.00 \\
Sum & 93.00 & 95.00 \\
& 1267.0 & 1306.00 \\
\hline
\end{tabular}

Information:

A1B2: kinesthetic learning style group students taught using the Brain-Based Learning (BBL) strategy

A2B2: kinesthetic learning style group students taught using the Project-Based Learning (PjBL) strategy

The ANOVA calculation results that student learning outcomes in basic introductory mathematics subjects taught by the Project Based Learning (PjBL) strategy are not different from the Brain-Based Learning (BBL) strategy. There is an interaction effect between Project-Based Learning Strategy (PjBL) and Brain-Based Learning Strategy (BBL) with learning styles on student learning outcomes with a level of confidence $\alpha=0,05$. While the mathematics learning outcomes of students who are taught the Project-Based Learning (PjBL) strategy are higher than Brain-Based Learning (BBL) especially in the kinesthetic learning style group based on t-Dunnet's advanced test calculations which indicate that $\mathrm{t}$.count $=-1.905<\mathrm{t} . \mathrm{tab}=-1.667$.

This finding shows that students with kinesthetic learning styles actively process information through physical means and this is very integrated with an emphasis on Project Based Learning strategies on skills to produce products and develop an atmosphere that requires students to develop their own knowledge. A meta-analysis of project-based learning is reported to have a positive effect on student academic achievement, encouraging students to be able to solve different problems far better than traditional learning but not based on education level and small group size (Chen \& Yang, 2019); Kinesthetic learning styles that highlight the role of project manipulation and planning, because kinesthetic learning styles actively process information through physical means can learn well when directly involved such as learning with projects (Menik \& Yuhendri, 2016). Thus the kinesthetic learning style students gain the support of project-based learning, giving students the freedom to carry out real projects collaboratively and students' oral communication skills. Collaboration and communication of students simultaneously performing at the $\mathrm{PjBL}$ stage provides a stronger understanding. activities with moderate intensity in mathematics learning can increase students' cognitive involvement (Owen, Parker, Astell-Burt, \& Lonsdale, 2018); problem-solving activities through project activities develop a better environment for the development of metacognition(Sart, 2014); experiments with PjBL connections with the real world were achieved (Efstratia, 2014); Project Methods Mathematics has an important influence on student performance compared to the "classic" Mathematical method (Stoica, 2015)

Besides that, in the curriculum of the mathematics education undergraduate program, the position of this course which contains the subject matter of the set and logic being a prerequisite for pure mathematics courses is reported to be appropriate if taught using project-based learning. Support for this finding that teacher self-efficacy can be positively affected by increased use of $\operatorname{PjBL}($ Choi et al., 2019); Project-based courses combine theoretical content from several subjects in higher education (creating, evaluating, analyzing) to advance students' technical skills (Choi et al., 2019); Adopting project-based learning is considered to create positive student competition (R., C., M., G., \& G., 2015)(50); Project Based, cooperation, sustainable energy (Verbic, Keerthisinghe, \& Chapman, 2017); multiple intelligences support Project Based Learning(Baş \& Beyhan, 2010); interaction of differences in individual cognitive processes and components of the self-learning model of new students at the strategy level is reported to have an effect on mathematical performance (Musso, Boekaerts, Segers, \& Cascallar, 2019); Learning styles and mathematical performance (Ma \& Ma, 2014); differences in learning styles and differences in creativity abilities (Huang, 2018).

\section{CONCLUSION}

The learning outcomes of students in the mathematics education department of the Faculty of Teacher Training and Education at Halu Oleo University were taught a higher Project Based Learning (PjBL) strategy compared to the Brain Based Learning Strategy (BBL) especially in the kinesthetic learning style group. This study found that students who have kinesthetic learning styles are more suitable to be taught with Project Based Learning (PjBL) learning strategies than Brain Based Learning (BBL) strategies. 


\section{ACKNOWLEDGMENT}

The Department of Mathematics Education, at the Faculty of Teachers and Education at Halu Oleo University in Kendari-Southeast Sulawesi, has supported the collection of research data

\section{REFERENCES}

1. Abdi, A., Rahmati, M., \& Ebadzadeh, M. M. (2019). Dictionary learning enhancement framework: Learning a non-linear mapping model to enhance discriminative dictionary learning methods. Neurocomputing. https://doi.org/10.1016/j.neucom.2019.05.004

2. Akyürek, E. (2013). Effects of Brain-Based Learning Approach on Students 'Motivation and Attitudes Levels in Science Class. Mevlana International Journal of Education (MIJE), 3(1), 104-119.

3. An, D., \& Carr, M. (2017). Learning styles theory fails to explain learning and achievement: Recommendations for alternative approaches. Personality and Individual Differences, 116(April), 410-416. https://doi.org/10.1016/j.paid.2017.04.050

4. Baker, M., Ali, M., \& French, E. (2019). The impact of women's representation on performance in project-based and non-project-based organizations. International Journal of Project Management, 37(7), 872-883. https://doi.org/10.1016/j.ijproman.2019.06.001

5. Balan, L., Yuen, T., \& Mehrtash, M. (2019). Problem-Based Learning Strategy for CAD Software Using Free-Choice and Open-Ended Group Projects. In Procedia Manufacturing. https://doi.org/10.1016/j.promfg.2019.02.223 silicalite synthesis. Materials Research Bulletin, 48(8), 2908-2914. https://doi.org/10.1016/j.materresbull.2013.04.040

7. Baş, G., \& Beyhan, Ö. (2010). Effects of multiple intelligences supported project-based learning on students' achievement levels and attitudes towards english lesson. International Electronic Journal of Elementary Education.

8. Bilgin, I., Karakuyu, Y., \& Ay, Y. (2015). The effects of project based learning on undergraduate students' achievement and self-efficacy beliefs towards science teaching. Eurasia Journal of Mathematics, Science and Technology Education. https://doi.org/10.12973/eurasia.2014.1015a

9. Cervantes, B. M. (2013). The impact of Project-Based Learning on mathematics and reading achievement of 7 th and 8th grade students in a South Texas school district. ProQuest Dissertations and Theses, (August), 103.

10. Chen, C. H., \& Yang, Y. C. (2019). Revisiting the effects of project-based learning on students' academic achievement: A meta-analysis investigating moderators. Educational Research $\begin{array}{llll}\text { Review (Vol. 26). Elsevier } & \end{array}$ https://doi.org/10.1016/j.edurev.2018.11.001

11. Chiang, C. L., \& Lee, H. (2015). The Effect of Project-Based Learning on Learning Motivation and Problem-Solving Ability of Vocational High School Students. International Journal of Information and Education Technology. https://doi.org/10.7763/ijiet.2016.v6.779

12. Ching-Ter, C., Hajiyev, J., \& Su, C. R. (2017). Examining the students' behavioral intention to use e-learning in Azerbaijan? The General Extended Technology Acceptance Model for E-learning approach. Computers and Education. https://doi.org/10.1016/j.compedu.2017.04.010

13. Choi, J., Lee, J. H., \& Kim, B. (2019). How does learner-centered education affect teacher self-efficacy?The case of project-based learning in Korea. Teaching and Teacher Education. https://doi.org/10.1016/j.tate.2019.05.005

14. Efstratia, D. (2014). Experiential Education through Project Based Learning. Procedia - Social and Behavioral Sciences, 152 1256-1260. https://doi.org/10.1016/j.sbspro.2014.09.362

15. Ergül, N. R., \& Kargın, E. K. (2014). The Effect of Project based Learning on Students' Science Success. Procedia - Social and Behavioral Sciences, 136, 537-541. https://doi.org/10.1016/j.sbspro.2014.05.371

16. Evrim, URAL\& Orhan, ERCAN \& Mehmet Akif, K. (2015). The Effects Of Students ' Learning Style Prefer- Ences On Their Academic Achievement In Science And Technology Class. International Journal of Social Science, 199-206.

17. Faramarzi, S., Samadi, M., Yarmohammadian, A., \& Dezhara, S. (2014). The Effectiveness of Brain Based Teaching on the Executive
6. Balbaşi, M. (2013). Application of full factorial design method to

Functions of the Students with Mathematics Learning Disability, 6(1), $1-16$. Retrieved

from

http://citeseerx.ist.psu.edu/viewdoc/download?doi=10.1.1.736.5153\& rep=rep $1 \&$ type $=$ pdf

18. Fatemeh Vizeshfar, \& Camellia Torabizadeh. (2018). The effect of teaching based on dominant learning style on nursing students' academic achievement. Nurse Education in Practice. https://doi.org/10.1016/j.nepr.2017.10.013

19. Glewwe, P., \& Muralidharan, K. (2016). Improving Education Outcomes in Developing Countries. In Handbook of the Economics of Education. https://doi.org/10.1016/B978-0-444-63459-7.00010-5

20. Gözüyeşill, E. (2014). The Effect of Brain Based Learning on Academic Achievement: A Meta-analytical Study *. Educational Consultancy and Research Center, 14(2), 642-648. https://doi.org/10.12738/estp.2014.2.2103

21. Gullick, J., Lin, F., Massey, D., Wilson, L., Greenwood, M., Skylas, K., ... Gill, F. J. (2018). Structures, processes and outcomes of specialist critical care nurse education: An integrative review. Australian Critical Care. https://doi.org/10.1016/j.aucc.2018.09.007

22. Hamdani, D. Al. (2015). Exploring Students' Learning Style at a Gulf University: A Contributing Factor to Effective Instruction. Procedia Social and Behavioral Sciences. https://doi.org/10.1016/j.sbspro.2015.01.452

23. Hong, J. C., Tsai, C. R., Hsiao, H. S., Chen, P. H., Chu, K. C., Gu, J., \& Sitthiworachart, J. (2019). The effect of the "Prediction-observation-quiz-explanation" inquiry-based e-learning model on flow experience in green energy learning. Computers and Education. https://doi.org/10.1016/j.compedu.2019.01.009

24. Huang, T.-C. (2018). Do different learning styles make a difference when it comes to creativity? An empirical study. Computers in Human Behavior. https://doi.org/10.1016/j.chb.2018.10.003

25. Izzati, N. (2014). PENGARUH PENERAPAN MODEL PEMBELAJARAN BERBASIS PROYEK TERHADAP KEMAMPUAN BERPIKIR KREATIF MAHASISWA (Studi Kuasi Eksperimen terhadap Mahasiswa Tadris Matematika IAIN Syekh Nurjati Cirebon). Eduma, 3(1), 77-91.

26. Kapadia, R. H. (2014). Level of Awareness about Knowledge, Belief and Practice of Brain based Learning of School Teachers in Greater Mumbai Region. Procedia - Social and Behavioral Sciences. https://doi.org/10.1016/j.sbspro.2014.01.1402

27. Li, Y., Zhang, T., Sun, S., \& Gao, X. (2019). Accelerating flash calculation through deep learning methods. Journal of Computational Physics. https://doi.org/10.1016/j.jcp.2019.05.028

28. Ma, V., \& Ma, X. (2014). A comparative analysis of the relationship between learning styles and mathematics performance. International Journal of STEM Education, $1(1), \quad 3$ https://doi.org/10.1186/2196-7822-1-3

29. McCabe, J. A. (2018). What Learning Strategies Do Academic Support Centers Recommend to Undergraduates? Journal of Applied Research in Memory and Cognition. https://doi.org/10.1016/j.jarmac.2017.10.002

30. Menik, K., \& Yuhendri, L. (2016). Analysis Characteristics of Learning Styles VAK (Visual, Auditory, Kinesthetic) Student of Banks and Financial Institutions Course. International Conference on Education For Economics, Business, and Finance.

31. Morgan, E., Fogel, A., Nair, A., \& Patel, A. D. (2019). Statistical learning and Gestalt-like principles predict melodic expectations. Cognition. https://doi.org/10.1016/j.cognition.2018.12.015

32. Moyer-Packenham, P. S., Lommatsch, C. W., Litster, K., Ashby, J., Bullock, E. K., Roxburgh, A. L., ... Jordan, K. (2019). How design features in digital math games support learning and mathematics connections. Computers in Human Behavior. https://doi.org/10.1016/j.chb.2018.09.036

33. Musso, M. F., Boekaerts, M., Segers, M., \& Cascallar, E. C. (2019) Individual differences in basic cognitive processes and self-regulated learning: Their interaction effects on math performance. Learning and Individual Differences, 71(July 2017), 58-70. https://doi.org/10.1016/j.lindif.2019.03.003

34. Ningsih, M. M. and Y. P. (2017). The Effects of Brain Based Learning Approach on Motivation and Students Achievement in Mathematics Learning. Journal of Physics: Conference Series, 895(1), 12057.

35. Ou, X., Chang, Q., \& Chakraborty, N. (2019). Simulation study on reward function of reinforcement learning in gantry work cell scheduling. Journal of Manufacturing Systems. https://doi.org/10.1016/j.jmsy.2018 .11 .005 
36. Owen, K. B., Parker, P. D., Astell-Burt, T., \& Lonsdale, C. (2018). Effects of physical activity and breaks on mathematics engagement in adolescents. Journal of Science and Medicine in Sport. https://doi.org/10.1016/j.jsams.2017.07.002

37. R., F., C., G., M., R., G., S., \& G., T. (2015). Using Project-Based-Learning in a mobile application development course-An experience report. Journal of Visual Languages and Computing. https://doi.org/10.1016/j.jvlc.2015.10.019

38. Saleh, S., \& Subramaniam, L. (2018). Effects of Brain-Based Teaching Method on Physics achievement among ordinary school students. Kasetsart Journal of Social Sciences, 4-8. https://doi.org/10.1016/j.kjss.2017.12.025

39. Sart, G. (2014). The Effects of the Development of Metacognition on Project-based Learning. Procedia - Social and Behavioral Sciences, 152, 131-136. https://doi.org/10.1016/j.sbspro.2014.09.169

40. Sedrakyan, G., Malmberg, J., Verbert, K., Järvelä, S., \& Kirschner, P. A. (2018). Linking learning behavior analytics and learning science concepts: Designing a learning analytics dashboard for feedback to support learning regulation. Computers in Human Behavior. https://doi.org/10.1016/j.chb.2018.05.004

41. Shuell, T. J. (2001). Learning theories and educational paradigms. In N. J. Smelser \& B. Baltes (Eds.), International Encyclopedia of the Social and Behavioral Sciences.

42. Stoica, A. (2015). Using Math Projects in Teaching and Learning. Procedia - Social and Behavioral Sciences, 180(November 2014), 702-708. https://doi.org/10.1016/j.sbspro.2015.02.181

43. Usher, E. L., Ford, C. J., Li, C. R., \& Weidner, B. L. (2019). Sources of math and science self-efficacy in rural Appalachia: A convergent mixed methods study. Contemporary Educational Psychology, 57, 32-53. https://doi.org/10.1016/j.cedpsych.2018.10.003

44. Valley, K. (2012). Learning styles and courseware design. Research in Learning Technology, 5(2). https://doi.org/10.3402/rlt.v5i2.10561

45. Verbic, G., Keerthisinghe, C., \& Chapman, A. C. (2017). A project-based cooperative approach to teaching sustainable energy systems. IEEE Transactions on Education. https://doi.org/10.1109/TE.2016.2639444

46. Viberg, O., Hatakka, M., Bälter, O., \& Mavroudi, A. (2018). The current landscape of learning analytics in higher education. Computers in Human Behavior. https://doi.org/10.1016/j.chb.2018.07.027

47. Waddington, J. (2019). Developing primary school students' foreign language learner self-concept. System, 82, 39-49. https://doi.org/10.1016/j.system.2019.02.012

48. Wang, Z., Gong, S. Y., Xu, S., \& Hu, X. E. (2019). Elaborated feedback and learning: Examining cognitive and motivational influences. Computers and Education, 136, 130-140. https://doi.org/10.1016/j.compedu.2019.04.003

49. Wen, Q. (2018). The production-oriented approach to teaching university students English in China. Language Teaching, 51(4), 526-540. https://doi.org/10.1017/S026144481600001X

50. Widiana, I. W., Bayu, G. W., \& Jayanta, I. N. L. (2017). Pembelajaran Berbasis Otak (Brain Based Learning), Gaya Kognitif Kemampuan Berpikir Kreatif Dan Hasil Belajar Mahasiswa. JPI (Jurnal Pendidikan Indonesia), https://doi.org/10.23887/jpi-undiksha.v6i1.8562

51. Yu, J., Zheng, X., \& Wang, S. (2019). A deep autoencoder feature learning method for process pattern recognition. Journal of Process Control. https://doi.org/10.1016/j.jprocont.2019.05.002

\section{AUTHORS PROFILE}

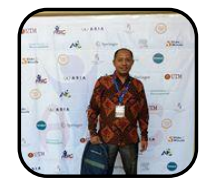

La Ode Ahmad Jazuli, Education Technology, Universitas Negeri Jakarta, Indonesia ldahmadjazuli.tp14s3@mahasiswa.unj.ac.id Indonesia. ahmadjazuli_laode@lecturer.uho.ac.id. S1 mathematics education study program, Halu Oleo University; S2 Mathematics Education Study Program, universitas

Negeri Surabaya.

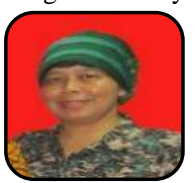

Etin Solihatin Education Technology, Universitas Negeri Jakarta, Indonesia etinsolihatin@ yahoo.com

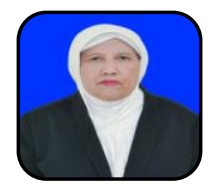

Zulfiati Syahrial Education Technology, Universitas Negeri Jakarta, Indonesia, .zulfiati@unj.ac.id 